\title{
Acceleration Factors in the Improvement of Public Welfare Sangiran
}

\author{
Mugi Raharjo, I Gusti Putu Diva Awatara, Harmadi, Wahyu Agung Setyo \\ Sebelas Maret University, Surakarta, Indonesia
}

\begin{abstract}
Efforts to preserve the cultural heritage are manifestation to represent the work of the ancestors of the past so that people can now take advantage of in accordance with destining. There are at least four major aspects of a cultural heritage can be appreciated to the public, as art, as an economic resource (for tourism and improve the welfare of the people in the region), as a source of information as knowledge and social fulfillment. This study aims to determine: (1) acceleration factors in the improvement of social welfare Sangiran; and (2) modernization of infrastructure and the role of maximum revenue acceleration in accelerating improvements in public welfare in the Sangiran with the integrated approach of the factors increasing human development, community empowerment, provision of credit banking and employment opportunities. This research is a survey of the Sangiran area using data collection methods of documentation, interviews, and questionnaires. The population in this study is people in the Sangiran region, Central Java. This study uses cluster sampling with sampling. Cluster sampling is a probability sampling extracted by certain groups with similar characteristics. In this study, samples were grouped according to the residence of respondents. The sample used in this study was 500 respondents. The analysis technique used is structural equation modeling (SEM). The results of this study show that: (1) the factors of human development, community empowerment, access to bank credit and employment opportunities to accelerate the improvement of social welfare in the Sangiran area; and (2) the acceleration of the increase in welfare Sangiran region can be achieved by an integrated approach of the factors increasing human development, community empowerment, bank lending and increase employment opportunities through increased infrastructure modernization and maximum income.
\end{abstract}

Keywords: human development, community empowerment, bank credit, employment opportunities, infrastructure, income, welfare

\section{Introduction}

Sangiran region have a lot of very interesting mysteries to uncover. The information contained in silence behind the hills at Sangiran is very important to the world of science. This is because the Sangiran sites were found the remains of past life which are very interesting to observe and learn. As the world's cultural heritage, Sangiran not only provides an overview of the physical evolution of humans alone but also able to provides a

Mugi Raharjo, Ph.D., Drs. M.Si, Senior Lecturer, Faculty of Economic, Sebelas Maret University.

I Gusti Putu Diva Awatara, SP. M.Si, Ph.D. Candidate of Environmental Science, Sebelas Maret University.

Harmadi, Drs. MM., Vice Dean, Faculty of Economic, Sebelas Maret University.

Wahyu Agung Setyo, Drs. M.Si, Lecturer, Faculty of Economic, Sebelas Maret University.

Correspondence concerning this article should be addressed to Mugi Raharjo, Faculty of Economic, Sebelas Maret University, Surakarta, Ir. Sutami 36 A Surakarta, 57126, Indonesia. E-mail: harryuns@gmail.com. 
clear picture of the evolution of culture, animals, and the environment as mandated by the vision and mission of preservation and development of the sustainability of Sangiran. Sangiran site as a center for the study of early human is able to provide maximum benefit at all the global, regional, national, and local levels.

Efforts to preserve the cultural heritage are actually one form to represent the work of the ancestors of the past so that people can now take advantage of in accordance with destining. There are at least four major aspects of a cultural heritage can be appreciated to the public, as objects of art, as an economic resource (for tourism and improve the welfare of the people in the region, for example), as a source of information science, and the social fulfillment (Hampton, 2005).

Sangiran is a potential area to be developed as a traditional cultural community-based tourism. This is caused by the background Sangiran still thick with the atmosphere of a traditional, though modernization has touched the lives of area residents. For the Sangiran, accepting modernization does not mean necessarily leave the local wisdom. The passion to create the harmony of human life with nature and the environment still characterize each individual action and communal activities. Tourism trends taking place in the last decade shows that those travelers tend tourist interested in natural shades. Tourism objects that sell exotic landscape and feel of a traditional society sell. Both local and foreign tourists in recent times experienced a change in consumption patterns. The travelers are no longer focused simply want to enjoy the beautiful natural scenery of the area, but also want to know even more intimate interaction into a pattern of public culture. With such a trend of tourism, community life, creative arts and culture, and heritage encapsulated in packages more attractive for tourists. The purpose of this study was to determine: (1) acceleration factors in the improvement of social welfare Sangiran; (2) modernization of the infrastructure and the role of maximum revenue acceleration in accelerating improvements in public welfare in the Sangiran with the integrated approach of the factors increasing human development, community development, administration bank credit, and increase employment opportunities.

\section{Literature Review}

\section{Human Development}

Human needs consists of three sides, namely: (1) basic life needs, it includes the needs of food, clothing, shelter and health; (2) social needs, covering education, recreation, transportation, internal and external interactions; and (3) developmental needs, including savings, special education and access to information (Soemardjan, 1997). The general sense is an attempt to promote the development of society and its citizens. The progress made by a society in economics. Based on the understanding, it can be given the understanding of human development as the progress made by the human society to meet the needs of the economy. However, this definition can be expanded, given the needs of the people that are not only economic, but also social, the human development can be given meaning as condition and the progress of human life is measured by its ability to meet the needs of life and social services (Budiman, 2004).

\section{Community Empowerment}

Ife (1995) states that empowerment is a process of helping disadvantaged groups and more individualized to compete effectively with other interests, by helping them to learn and use in lobbying, using the media, engaging in political action, understanding how to work the system and so on. The above definition defines the concept of empowerment as an effort to provide autonomy, authority, and trust to every individual in an organization, and 
encourage them to be creative in order to complete the task as possible. Foy (1994) states empowerment is often interpreted as an effort to provide power in order to hear their aspirations in order to contribute to the planning and decisions that affect their communities.

Budiman (2004) states the general sense is an attempt to promote the development of society and its citizens. The progress made by a society in economics. Based on the understanding, it can be given the understanding of human development as the progress made by the human society to meet the needs of the economy. However, this definition can be expanded, given the needs of the people that are not only economic, but also social, the human development can be given meaning as condition and the progress of human life is measured by its ability to meet the needs of life and social services.

Community empowerment is a concept that summarizes the economic development of social values. This concept reflects the new development paradigm, namely that is "people centered, participatory, empowering, and sustainable" (Chambers, 1995). This concept is broader than merely satisfy basic needs (basic needs) or provide a mechanism to prevent further impoverishment (safety net), whose thinking recently been developed as an effort to find an alternative to the concepts of growth in the past. This concept evolved from the efforts of many experts and practitioners to find out what the others by Friedman (1992) referred to as alternative development, which requires inclusive democracy, appropriate economic growth, gender equality, and intergenerational equal.

\section{Banking Credit}

Credit is the delay in the payment of the loans given current achievements in the form of goods, money or services profits or interest obtained from the lender to maintain business continuity and expand its business (Tohar, 2000). Samuelson and Nordhaus (2004) reason for credit request is a request that needs a medium of exchange transactions received by the general public to buy goods and pay bills, and in addition to that asset or as a store of value. Request credit be affected by interest rate (cost of holding money) where the higher cost (interest rate) and the demand for credit (money) decreased.

Money demand for credit purposes is determined by the interest rate. The higher the interest rate is, the lower the community's desire for credit is. The reason is if the interest rate rise means the cost of holding money (opportunity costs) vanishingly small, whereas the lower the interest rate, the greater the public's willingness to borrow loans (Tambunan, 2001).

\section{Employment Opportunities}

Tambunan's (2001) definition of employment has included jobs that are already occupied and vacant (vacancy), while Djuhari (1998) states implies employment jobs and jobs created to be filled through an economic activity (production) so employment includes jobs are already filled and all the jobs that have not been filled and are commonly known as job requirements.

Makmun (2004) states that the measure of economic progress include national income, employment rate, the price level, and the foreign payments position. Nationally suggests that the economic collapse of industries in urban areas resulted in the rural economic growth and rising unemployment as a result of increased migrants return to the village. Easements government capital for the development of the SME sector will be able to overcome the leveling off (reduction of capacity) and increase profits. Development of agribusiness and agro-industries in rural areas will also be able to increase productivity, income, and employment opportunities so 
that populations will increase aggregate supply.

\section{Infrastructure}

World Bank (2007) defines infrastructure as the physical assets needed to support economic activity both in production and final consumption includes public utilities (energy, telecommunications, water supply, sanitation, and gas), public work (roads, dams, canals, irrigation channels, and drainage) and the transport sector (road, rail, transit ports, airports and so on).

The linkage between infrastructure and economic growth cannot be separated from the function as with infrastructure enabler of economic activity. Infrastructure has the tools to drive various sectors of the economy as it is considered as social overhead capital (Permana, 2009). As a region, Sangiran course requires physical infrastructure as a facility that will support all activities carried out in the region. In general, the infrastructure include: infrastructure related to transportation of goods and people, such as roads and other logistics facilities, infrastructure as a provider and supplier of energy such as electricity and other energy generating stations, sewage treatment and storage infrastructure such as water treatment and others as well telecommunications infrastructure such as telephone and communication (Djajadiningrat \& Melia, 2004).

\section{Revenue}

Baridwan (2004) revenues are inflows of other assets or an increase in a business entity or settlement of its debts (a combination of both) during a period from the delivery or manufacture of goods, delivery of services or other activities that constitute the main activity of the enterprise. Dycman (2002) says that revenues are inflows or other enhancements of assets or settlement of liabilities an entity or a combination of the two during the period of delivery or production of goods, provision of services or other activities that are major or central operations ongoing entity. Syafri (2002) defines gross income as an increase in assets and a decrease in the gross liability assessed by accounting principles derived from profit-seeking activities.

Revenue should be presented fairly, not to be anticipated too big or too small. Measurement revenues by Indonesian Institute of Accountants (2004) explained that the revenue should be measured by the fair value of the consideration received or to be received, the Indonesian Institute of Accountants further stated that the amount of revenue arising from a transaction is usually determined by agreement between the company and the buyer or user assets. The amount is measured by the fair value of the consideration received or receivable the company reduced the number of trade discounts and volume rebates earned by the company.

\section{Welfare}

Sen (2002) says that welfare economics is a rational process towards the public release of the barriers to progress. Social welfare can be measured from measures such as the level of life (levels of living), fulfillment of basic needs (basic needs fulfillment), quality of life (quality of life), and human development, while Nicholson (1992) argues that the principle of the social welfare state welfare social maximum is reached when no one was harmed. Swasono (2004) propose performance criteria for social welfare with restrictions that include output growth, efficiency, stability, security, inequality, and the freedom that should be associated with a social preference, while Etzioni (1999) says that the privacy of individuals related by social norms, and thus the position of the individual is as social beings who must find in economics primarily in economic development aimed towards the welfare of society. 


\section{Research Methods}

This research is the correlation by using primary data through a survey with interview techniques (direct interview) to the respondents with the help of a structured questionnaire (questionnaire) contains about human development, community development, banking credit, employment, infrastructure, income, and welfare.

The population in this study is people in the Sangiran region, Sragen, Central Java. This study uses cluster sampling with sampling. Cluster sampling is a probability sampling extracted by certain groups with similar characteristics. In this study, samples were grouped according to the residence of respondents. Sampling method was used for this study will take a sample based on specific goals quickly. The sample used in this study was 500 respondents.

Operational definitions of the variables used in this study are:

(1) Human development is the progress made by the human society in meeting the needs of the economy, measured by the human development index (HDI) covering aspects of health and longevity read of the life expectancy, educational aspect views of the old school and buying power.

(2) Community empowerment is a process of development potential and ability that grows the capacity to solve the problems facing society. Community empowerment is measured by the success of awareness and community organizing.

(3) Bank credit is the provision of a number of funds offered by banking institutions to the public for business. Bank lending is measured by the ease of access and procedure.

(4) Job opportunity is that jobs and vacancies are created to be filled through an economic activity (production). Employment opportunities are not easily measured or employment opportunities.

(5) Infrastructure is a public facility and infrastructure in support of economic activities in the area of Sangiran. Infrastructure measured by eligibility transportation infrastructure, irrigation, housing, and buildings and public utilities.

(6) Income is income households (head of the family, father, mother, and children who are already working) regular monthly as salaries, wages, and benefits. Income measured in dollars.

(7) The welfare of society is a rational process towards the public release of the barriers to progress. Social welfare is measured by the fulfillment of basic needs (basic needs fulfillment) and livelihood (levels of living).

The analysis technique used is structural equation modeling which is a technique that combines elements of multiple regression and factor analysis. This technique will also examine the relationship between different variables or constructs simultaneously, so it will be beneficial when the dependent variable to the independent variable in the next relationship. To test this hypothesis in this study we used Maximum Likelihood Estimation (ML) with the program Amos Version 5 through Maximum Likelihood Estimation will get the value of critical ratio (CR) which is identical to the $t$ test in Multiple Linear Regression, where the value of CR accepted if it has a value equal to or greater than two (Ferdiand, 2000).

\section{Data Analysis}

\section{Goodness of Fit Test}

$X^{2}$ value in this study amounted to 276.571 with a probability of 0.063 is a good indication. GFI value of 0.954 means that are qualified to be expected and RMSEA value of 0.017 is a good indication. While the 
incremental fit index AGFI value obtained measures of 0.943 means it meets the expected requirements and CFI values of 0.956 and 0.950 for mean TLI has been qualified to be expected. In addition to the parsimony fit index measures the value obtained CMIN/df of 1.143 is a good indication because it has a smaller value than two. These results indicate that the model is built gives Goodness of Fit Index value that meets the requirements of the model.

\section{Hypothesis Test}

The estimation of structural models in this study can be seen in Table 1:

Table 1

The Result of Structural Equation Model Estimation

\begin{tabular}{llll}
\hline Regression Weights & C.R. & $p$ & Criteria \\
\hline $\mathrm{I} \leftarrow \mathrm{PM}$ & 3.375 & $0.000^{* * *}$ & 0.01 \\
$\mathrm{I} \leftarrow \mathrm{DM}$ & 2.168 & $0.030^{* *}$ & 0.01 \\
$\mathrm{I} \leftarrow \mathrm{KP}$ & 3.025 & $0.002^{* * *}$ & 0.01 \\
$\mathrm{I} \leftarrow \mathrm{KK}$ & 7.830 & $0.000^{* * *}$ & 0.01 \\
$\mathrm{P} \leftarrow \mathrm{PM}$ & 2.009 & $0.045^{* *}$ & 0.05 \\
$\mathrm{P} \leftarrow \mathrm{DM}$ & 2.206 & $0.027^{* *}$ & 0.05 \\
$\mathrm{P} \leftarrow \mathrm{KP}$ & 2.386 & $0.017^{* *}$ & 0.05 \\
$\mathrm{P} \leftarrow \mathrm{KK}$ & 4.360 & $0.000^{* * *}$ & 0.01 \\
$\mathrm{KM} \leftarrow \mathrm{I}$ & 2.076 & $0.038^{* *}$ & 0.05 \\
$\mathrm{KM} \leftarrow \mathrm{P}$ & 3.124 & $0.002^{* * *}$ & 0.01 \\
$\mathrm{KM} \leftarrow \mathrm{PM}$ & 4.251 & $0.000^{* * *}$ & 0.01 \\
$\mathrm{KM} \leftarrow \mathrm{DM}$ & 3.151 & $0.002^{* * *}$ & 0.01 \\
$\mathrm{KM} \leftarrow \mathrm{KP}$ & 3.213 & $0.002^{* * *}$ & 0.01 \\
$\mathrm{KM} \leftarrow \mathrm{KK}$ & 3.321 & $0.000^{* * *}$ & 0.01 \\
\hline
\end{tabular}

Notes. PM = Human Development; DM = Empowerment; KP = Bank loans; KK = Employment opportunities; I = Infrastructure; $\mathrm{P}=$ Revenue; $\mathrm{KM}=$ welfare society ${ }^{* *}=$ Significant at the $5 \%$ error; ${ }^{* * *}=$ Significant at $1 \%$ error. Source: Data analysis, 2012.

\section{Results}

(1) In order to accelerate the improvement of social welfare in the Sangiran area, efforts should be taken:

- Increasing human development in the region's Krikilan, Ngebung, Bukuran, and Dayu through efforts to provide educational scholarship programs for school children and training activities such as training of conservation and tourism development in the village of Krikilan, Ngebung, Bukuran, and Dayu and training need assessment (TNA) for local and community development efforts in the field of handicrafts/souvenirs;

- Increasing the empowerment of communities through efforts to provide a variety of community programs such as community development efforts in the areas of accommodation, home stay and restaurants in clusters Krikilan, production process technology training in the field of batik, souvenirs and crafts at the cluster Bukuran, management training business management, developed a tourism awareness groups (Pokdarwis) in each village. Development of tourism awareness groups can observe aspects in an integrated area development Sangiran Krikilan e.g., for cluster development directed to the appreciation of the history of human civilization. For those communities that exist in the cluster should at least understand Krikilan, Krikilan cluster region as an appreciation of history of human civilization so expect existing community empowerment can be adjusted with the ability or potential businesses in the cluster region Krikilan that can be adapted to the cluster development 
concept Krikilan. Likewise, for the communities in the cluster can be empowered in accordance Ngebung, Ngebung cluster development as an appreciation of the history of the discovery of fossils of Sangiran site. For the cluster can be empowered in accordance Bukuran, Bukuran cluster development as information accumulated appreciation fossils Sangiran site (history of java man) and cluster Dayu appreciation Sangiran excavation of fossil sites and cutting-edge research;

- Increasing the bank loan by the government to provide capital access to both banking institutions Banks and Bank Syariah to the public by a group of credit without collateral given to the people who have started businesses and credit application procedure is not complicated;

- Increasing employment opportunities by involving the active participation of the community in the development of the area in each cluster through involvement in developing the unique nature, fossils, handmade souvenirs, and tourist attraction as well as the existing research on cluster Krikilan could be involved in the construction and development study center, convention center and recreational water clusters Krikilan. For cluster Ngebung community can be involved in the management of the indoor museum, while the cluster Bukuran community can be involved in managing the souvenir shop. Other than that involved in the development of restaurants and restaurant, amphitheater construction multimedia, entertainment stage construction, installation of signs tours, jungle tours development, construction, and fishing floating resto in Dam Bapang and land acquisition in the area of Sangiran.

(2) Accelerating the improvement of social welfare in the Sangiran can be achieved through the modernization of infrastructure and revenue maximized. Infrastructure modernization efforts in the area of Sangiran can be done through:

- Repair or improved drainage and pavement construction for example, in a village location Jetis Karangpung, construction of major roads such as relatively long bridge worth in District Kalijambe and Plupuh;

- Construction of drainage and sidewalks driveways Sangiran Museum;

- Installation of street lighting in the village or mercury Jetis Karangpung;

- Construction of road paving in locations where fossil discoveries cluster Krikilan, Ngebung, Bukuran, and Dayu;

- Development checkpoint on cluster Ngebung, Bukuran, and Dayu;

- Improvement path toward Pungsari Sangiran, road improvements Kragilan towards Ngebung, Sangiran towards Bapang roadwork, road improvements and repairs Sangiran towards Dayu From leading Pungsari;

- Maintenance of secondary channels in Jetis Karangpung, Wonorejo, Kaliwuni, Bapang, Sambirejo, and Citran;

- Improvement neighborhoods such as drainage improvements, street paving, and the provision of more and improved bins or carts;

- Improvement ponds Ngebung.

(3) Efforts to increase the maximum income can be done through:

- Accelerate the number of permanent stalls Sangiran region;

- Accelerate the construction of facilities catering service provider (restaurant) in the Sangiran area with facilities that have a standard of comfort and hygiene;

- Accelerate the construction of the gallery souvenirs at Sangiran area; 
- Accelerating the provision of working tools owned by the artisan souvenirs at Sangiran area;

- Accelerate the provision of working capital held by the craftsmen to develop the business;

- Accelerating the provision of quality craft products produced by the public so that the need for training to improve the skills of craftsmen.

\section{Conclusions}

Human development, community development, banking credit, and employment opportunities have positive effects on social welfare. These results indicate that increasing human development, community empowerment, bank credits, and employment opportunities can accelerate the improvement of social welfare in the Sangiran area.

Accelerating the improvement of social welfare in the Sangiran can be achieved with the integrated approach of the factors increasing human development, community development, bank lending, and increase employment opportunities through increased infrastructure modernization and maximum income.

Some recommendations can be associated with this study are as follows:

(1) Increasing human development can be done through education scholarships for children and training activities such as training of conservation and tourism development in the village of Krikilan, Ngebung, Bukuran, and Dayu and training needs assessment (TNA) for local and community development efforts in the field of handicrafts/souvenirs.

(2) Increasing the empowerment of the community through efforts to provide a variety of community programs such as community development efforts in the areas of accommodation, home stay, and restaurants in clusters Krikilan, production process technology training in the field of batik, souvenirs and crafts at the cluster Bukuran, management training business management, developed a tourism awareness groups (Pokdarwis) in each village.

(3) Increasing the bank loan by the government to provide capital access to both banking institutions Banks and Bank Syariah to the public by a group of credit without collateral given to the people who have started businesses and credit application procedure is not complicated.

(4) Increasing employment opportunities by involving the active participation of the community in the development of the area in each cluster through involvement in developing the unique nature, fossils, handmade souvenirs, and tourist attraction as well as the existing research.

(5) Efforts to modernize infrastructure in the Sangiran area can be done through:

- Preparation of the special facilities for disabled people in the cluster Krikilan;

- Repair or improved drainage and pavement construction, for example, in a village location Jetis karangpung, construction of major roads such as relatively long bridge worth in District Kalijambe and Plupuh;

- Construction of drainage and sidewalks driveways Sangiran Museum;

- Construction of road paving in locations where fossil discoveries cluster Krikilan, Ngebung, Bukuran, and Dayu;

- Development checkpoint on cluster Ngebung, Bukuran, and Dayu;

- Improvement neighborhoods such as drainage improvements, street paving and the provision of more and improved garbage bins or carts and repair ponds Ngebung. 
(6) Efforts to increase the maximum income can be done through:

- Accelerate the number of permanent stalls Sangiran region;

- Accelerate the construction of facilities catering service provider (restaurant) in the Sangiran area with facilities that have a standard of comfort and hygiene;

- Accelerate the construction of the gallery souvenirs at Sangiran area;

- Accelerate the provision of working tools owned by the artisan souvenirs at Sangiran area;

- Accelerate the provision of working capital held by the craftsmen to develop the business;

- Accelerate the provision of quality craft products produced by the public so that the need for training to improve the skills of craftsmen;

- Provide outreach to the community to plant plants that fit the soil conditions in the area without damaging the Sangiran site such as fruit crops like citrus Tawangmangu once famous. options productive agricultural cultivation will be more supportive of Sangiran as a tourist area and address critical land;

- Entertainment in the form of traditional art such as art Tayub to be further developed, for serving tourists on any given day. This has been initiated and implemented and the results have increased the flow of tourists to the region Sangiran.

(7) Making packages in collaboration with travel agents will also be able to represent the presence of the Sangiran. For packages that need to be planned field trips to locations outcrop soils containing findings and describing stratigraphic outcrop of land ranging from the oldest to the youngest layer. This package must be supported by a reliable guide to explain the history of geology Sangiran well. Target eventually expected to show Mueum Sangiran useful educational cultural treat for visitors to the museum community. Gradually each community will be formed a positive attitude towards the preservation of the national culture.

(8) Required ongoing coordination and collaboration with all stakeholders of the central government, provincial governments, district/municipal, private, universities/academics, NGOs, and the whole community in the development of the Sangiran.

\section{References}

Baridwan, Z. (2004). Intermediate accounting. Yogyakarta: BPFE.

Budiman, A. (2004). Third world development theory. Jakarta: Gramedia.

Chambers, R. (1995). Rural development: From rear. Jakarta: LP3ES.

Djajadiningrat, S. T., \& Melia, F. (2004). Environmental industrial zone (Eco industrial park). Bandung: Engineering Science.

Djuhari, M. (1998). Shadow of classical economics. Jakarta: Directorate General of Higher Education.

Dycman, D. D. (2002). Intermediate accounting. Jakarta: Erlangga.

Etzioni, A. (1999). Comparative analysis of complex organizations. USA: The Free Press of Glencoe, Inc..

Ferdiand, A. (2000). Structural equation modeling in management research, Semarang: BP. UNDIP.

Foy, N. (1994). Empowering people at work. London: Grower Publishing Company.

Friedman, J. (1992). Empowerment the polities of alternative development. USA: Blackwell Publishers, Cambridge.

Hair, J. F., Anderson, R. E., \& Tatham, R. L. (1998). Multivariate data analysis. New Jersey, N.J.: Prentice Hall.

Hampton, M. P. (2005). Heritage, local communities and economic development. Annuals of Tourism Research, 32(3), 735-759.

IAI. (2004). Financial accounting standards. Jakarta: Four Salemba.

Ife, J. W. (1995). Community development: Creating community alternatives-vision, analysis and practice. Melbourne: Longman.

Kieso, D. E., Weygandt, J. J., \& Terry, D. W. (2002). Intermediate accounting. Jakarta: Erlangga Publishing.

Makmun. (2004). Effect of availability of employment and the formation of the value added investment in the manufacturing sector: A case study in Batam. Study of Economy and Finance, 8(1), 19-31. 
Nicholson, W. (1992). Microeconomics theory. New York: The Dryden.

Permana, C. D. (2009). The role and impact analysis of infrastructure investment on Indonesian economy. Bogor: IPB Press. Samuelson, P. A., \& Nordhaus, W. D. (2004). Macroeconomic sciences. Jakarta: PT. Global Media Education. Sen, A. (2002). Development as freedom. Oxford: Oxford University Press.

Soemardjan, S. (1997). Poverty: A view of sociology. Jakarta: ISI Publisher.

Swasono, S. E. (2004). Economic system and economic democracy. Jakarta: UI Press.

Syafri, S. H. (2002). Critical analysis of financial statements. Jakarta: PT. King Grafindo Perkasa.

Tambunan, T. (2001). Indonesia's economic transformation: Theory and empirical discovery. Jakarta: Indonesia Ghalia.

Tohar, M. (2000). Capital and credit cooperatives. Yogyakarta: Kanisius.

World Bank. (2007). Indonesia public expenditure chapter 5 infrastructure. Retrieved November 22, 2009 from http://siteresources.worldbank.org/INTINDONESIA/Resources/2262711168333550999/PERFBAB5-Infrastruktur.pdf 